\title{
II. JAK WYKORZYSTAĆ NARZĘDZIA CYFROWE W PROCESIE WYCHOWANIA? PROPOZYCJA DLA DZIECI I MŁODZIEŻY
}

Wychowanie na przestrzeni wieków ulegało przemianom. Jedną z przyczyn tych modyfikacji był fakt, że wychowankami stawały się kolejne pokolenia - inne niż te, wobec których uprzednio przebiegał proces wychowawczy. Wydaje się jednak, że obecnie nie tylko kolejne pokolenia są bardziej zróżnicowane od poprzednich, ale także zachodzące w świecie zmiany powodują, iż nawet generacje zbliżone wiekiem różnią się znacząco i wymagają innego stylu oddziaływania. To również sprawia, że coraz częściej wychowawcy z trudem odnajdują właściwy sposób dotarcia do swych podopiecznych.

Dzisiejsze dzieci i młodzież zalicza się do generacji Z - tak klasyfikowane są „osoby urodzone po 1995 roku, dla których technologia to główne narzędzie do poszerzania wiedzy". ' Osoby reprezentujące pokolenie Z nie tylko swą wiedzę wzbogacają przy zastosowaniu nowoczesnych środków technicznych - również rozrywka i czas wolny odbywają się z użyciem tychże narzędzi. Dla wychowawców jest to wyraźną podpowiedzią, że chcąc oddziaływać na opisywaną grupę wiekową, nie tylko nie można lekceważyć cyberprzestrzeni, ale także zastanowić się, w jaki sposób wykorzystać jej walory do formowania młodych ku pełni człowieczeństwa.

Już samo korzystanie przez dzieci i młodzież z narzędzi cyfrowych jest wyzwaniem wychowawczym. Wprawdzie młody użytkownik Sieci dobrze sobie radzi z poruszaniem się w świecie wirtualnym, to jednak w większości przypadków jest to sprawność techniczna, ograniczająca się do umiejętności czy sprawności w obsłudze programów, gier czy portali. Znacznie mniej istotą kwestią jest dlań zagrożenie związane z obecnością w cyberprzestrzeni. Wychowawca winien zatem w swej pracy uwzględnić cały obszar zagadnień związanych z bezpiecznym korzystaniem przez wychowanków z tych mediów. Aby przekaz ten był skuteczny, nie można ograniczać się do formy wykładu. Cenne będzie $\mathrm{m}$. in. odwołanie się do konkretnych przykładów, wypowiedzi osób dotkniętych jednym z niebezpiecznych zjawisk w sieci (cyberbullyingiem, sekstingiem, hejtowaniem czy dostępnością niepożądanych treści).

1 Pokolenie Z-technologię ma we krwi, http://www. nzb. pl/aktualnosci/38-pokolenie-z (dostęp: 6 XI 2015). 
Dzisiejszy uczeń doskonale zna nowoczesne technologie informacyjno-komunikacyjne i nie będzie przesadą stwierdzenie, że to nauczyciel, wychowawca może wiele nauczyć się od niego pod tym względem. Ta swoista zamiana ról również może być wykorzystana w procesie wychowawczym dorosły winien dowartościować umiejętności swego wychowanka. Wyrazem tego będzie $\mathrm{m}$. in. umożliwienie młodemu człowiekowi wypowiedzi odnośnie do tego, w jaki sposób on sam postrzega swój udział w wirtualnej rzeczywistości - do czego używa narzędzi cyfrowych, czemu one służą. Warto również umożliwić pozwolić wypowiedzieć i zaproponować mu współtworzenie materiałów czy pomocy, które następnie będą wykorzystane. Odpowiedzi mogą ukierunkować na to, co możemy rozważyć jako potencjalną pomoc dydaktyczną czy wychowawczą. ${ }^{2}$ Zamiast referatu na dowolny temat, warto zadać uczniom pracę polegająca na podzieleniu się wiedzą, umiejętnościami z zastosowaniem technologii informacyjno-komunikacyjnych (TIK). Analogicznie można wykorzystać propozycję w przypadku oddziaływań wychowawczych - zaangażowani uczniowie na pewno chętnie nagrają krótki filmik o tym, jak włączają się w akcję charytatywną, czy działają w inny sposób. W jeszcze większym stopniu wykorzystamy cyberprzestrzeń w działalności wychowawczej, jeśli powyższe propozycje połączymy z uświadamianiem dzieciom czy młodzieży, że nasze uczestnictwo w wirtualnej rzeczywistości nie powinno ograniczać się jedynie do czerpania z niej czegoś dla siebie, lecz każdy może - stosownie do swych talentów i umiejętności - wzbogacać tę rzeczywistość, zamieszczając w niej własne dzieła i udostępniając je innym użytkownikom.

Inną możliwością zastosowania Internetu w działalności wychowawczej jest wykorzystywanie cyberprzestrzeni do ukazywania dzieciom i młodzieży wzorców osobowych. Kiedy uczniowie samodzielnie przebywają w Sieci, nierzadko znajdują tam swoich „bohaterów” - często jednak są to postaci, których bynajmniej nie powinni naśladować. Świadomi tego wychowawcy - zamiast próbować walczyć z tym, na co często jest przyzwolenie rodziców, czyli z niekontrolowanym korzystaniem z Internetu, winni ukazać jego pozytywne aspekty. Istnieje wiele wartościowych stron www oraz portali - w tym również katolickich - dostępnych dla użytkowników w różnym wieku. Niejednokrotnie swą szatą graficzną z powodzeniem

2 Przykładem może być konkurs Moj@ edukacja, którego jeden z laureatów podzielił się pomysłem cyfrowych map myśli, zaś inna uczennica (gimnazjum) nagrywa doświadczenia u udostępnia rówieśnikom. 
dorównują „świeckim”, zaś pod względem treści i poziomu przewyższają wiele z tych, które są regularnie odwiedzane przez dzieci i młodzież. Choć nie należy oczekiwać, że podopieczni niemal natychmiast zmienią swe zainteresowania i będą odwiedzać już tylko strony katolickie, to istotne jest, by w ogóle dowiedzieli się, gdzie mogą szukać odpowiedzi na pytania związane ze sferą religijną lub moralną, kiedy takowe zaczną się pojawiać. Trudno nie dostrzec, że w Internecie łatwo jest odnaleźć wszystko - nie ma jednak gwarancji, iż odnaleziona odpowiedź będzie prawidłowa i udzielona przez kompetentne osoby. Łatwość korzystania z mediów i anonimowość zapewniana w Sieci sprawia, że często osoby wypowiadające się na dany temat nie mają ku temu żadnych kompetencji, a wręcz wprowadzają innych w błąd. Dobrze zatem byłoby, aby wychowawcy uświadamiali również tę kwestię swym wychowankom, odwołując się do konkretnych wypowiedzi.

Rozmowy ze starszymi dziećmi i młodzieżą potwierdzają, że przedstawiciele pokolenia $Z$ dobrze znają pojęcia trollowania, spamowania, hejtu... Warto jednak uświadamiać im, że w świecie cyfrowym - niezależnie od etykiety - Dekalog nie przestawał obowiązywać. Zadanie chrześcijańskich wychowawców powinno zmierzać do tego, by mówiąc o wykroczeniach przeciw Bożym przykazaniom, nie zapominali o tych, które wiążą się z obecnością w świecie cyfrowym. Warto wręcz razem z uczniami stworzyć swoisty Dekalog internauty i wmiarę możliwości poszczególne przykazania odnieść do korzystania z narzędzi cyfrowych. Zadaniem nie tylko dla katechety, ale także dla wychowawcy, może być również opracowany wraz z uczniami „rachunek sumienia internauty”. W tego typu działaniach nie chodzi jednak o to, by uczniowie wobec kolegów i koleżanek udzielali odpowiedzi na kolejne pytania związane z ich działalnością w cyberprzestrzeni, lecz mogli w domu indywidualnie przeanalizować swe postępowanie.

Przebywając w wirtualnej rzeczywistości, młodzież niewątpliwie korzysta również z forów dyskusyjnych, zatem przedmiotem oddziaływań wychowawczych warto uczynić ten aspekt obecności w Sieci. Istotnym zadaniem chrześcijańskiego wychowawcy będzie przygotowanie uczniów do należytego formułowania własnych opinii i wyrażania poglądów. Ich uwadze może bowiem uchodzić to, że inne osoby komentujące ten sam artykuł czy wpis nadal pozostają bliźnim, wobec którego mamy konkretne zadanie miłości chrześcijańskiej. Warto również zachęcać młodzież do pisanie blogów, zwracając uwagę na to, że tego rodzaju twórczość może stanowić rodzaj świadectwa przez konkretne deklaracje wobec rozmaitych zagadnień, ludzkich postaw czy bieżących wydarzeń opisanych 
w Internecie. Konkretną propozycją może być np. konkurs na blog dla kandydata do bierzmowania. Walorem tej formy dziennika internetowego jest jej interaktywność. Nie tylko zatem autor wyraża swe poglądy i stanowisko wobec rozmaitych kwestii, ale także nierzadko wykazuje umiejętność argumentowania własnych racji i obrony swego zdania. Powinien bowiem liczyć się z tym, że komentarze dotyczące jego wpisów mogą mieć różny charakter, czasem wymagając od blogera polemizowania z komentatorami lub innego reagowania na ich wypowiedzi.

Spośród różnorodnych narzędzi oferowanych przez cyberprzestrzeń, szczególną uwagę warto zwrócić na portale społecznościowe. Uczniowie chętnie korzystają z nich - nierzadko nawet wtedy, gdy jeszcze regulamin portalu zabrania tego. ${ }^{3}$ Czasem wychowawca przyjmuje zaproszenie do grona znajomych ze strony uczniów - należy jednak rozważyć tę sytuację, szczególnie jeśli dotyczy ona uczniów szkoły podstawowej. Skoro są to uczniowie, w świetle regulaminu nie mający prawa do posiadania konta na Facebooku, niewychowawcze byłoby pozytywne odpowiadanie na wysłane przez nich zaproszenia, ponieważ wychowawca w ten sposób niejako akceptuje fakt nieprzestrzegania przepisów regulujących udział wychowanka w tejże wirtualnej społeczności.

W odniesieniu do uczniów powyżej 13. roku życia, warto jednak korzystać z kontaktu, jaki umożliwia portal społecznościowy. Znajomość podtrzymywana na tym portalu pozwala wychowawcy lepiej orientować się w tym, czym żyje wychowanek - co lubi, jakie ma zainteresowania, w jakich wydarzeniach uczestniczy, a nawet w jaki sposób komunikuje się ze znajomymi (na jakim poziomie). Ponadto kontakt za pośrednictwem portalu społecznościowego może być swego rodzaju przedłużeniem kontaktów szkolnych. Tą drogą wychowawca może angażować uczniów do udziału w różnego typu akcjach, zachęcać do występowania przeciw zachowaniom nieakceptowanym czy przeciwnie - wyrażać swe poparcie dla cennych

3 Tak jest w przypadku portalu Facebook, który umożliwia korzystanie użytkownikom od 13. roku życia. W praktyce jednak korzystają z niego już osoby znacznie młodsze. Zauważalna jest także tendencja zakładania kont na Facebooku małym dzieciom przez ich rodziców. Takie zachowanie szczególnie domaga się szerokiego komentowania, ponieważ zakładając konto dziecku poniżej regulaminowego wieku, rodzice nie tylko łamią ten regulamin, ale także w formularzu rejestracyjnym podają nieprawdziwe informacje odnośnie do roku urodzenia dziecka. W przeciwnym przypadku konto nie byłoby utworzone. 
inicjatyw, do których zaprasza także swych podopiecznych. Możliwości te są dla obu stron - również uczniowie mogą organizować wydarzenia i podejmować inicjatywy - także o charakterze religijnym - do udziału w których zaproszą swego wychowawcę. W odniesieniu do dzieci portale społecznościowe mogą stać się płaszczyzną kontaktu z rodzicami, np. przez utworzenie grupy zamkniętej. Dodawane przez wychowawcę informacje będą wówczas docierały jednocześnie do wszystkich rodziców należących do grupy, zaś rodzice będą mogli w dogodnym czasie zareagować na wpisy. Jest to rozwiązanie bardziej komfortowe niż choćby szkolne konsultacje, których termin pokrywa się zwykle z godzinami pracy rodziców ucznia.

Inną propozycją wspomagania działalności wychowawczej wobec dzieci i młodzieży jest newsletter - zarówno dla uczniów jak i/lub dla rodziców. Rozumiany jako cykl wysyłanych przez wychowawcę maili, umożliwia przesyłanie uczniom dodatkowych treści poszerzających zagadnienia podjęte na lekcji, wzbogacone o konkretne zadania do podjęcia. Mogą to być także odnośniki do ciekawych stron i akcji, do udziału w których nauczyciel zachęca dzieci i młodzież. W przypadku newslettera dla rodziców, warto zaproponować w nim pewne działania do podjęcia na gruncie rodziny, związane z przeprowadzoną lekcją czy podejmowanymi obszarami tematycznymi. Wprawdzie forma ta nie gwarantuje realizacji proponowanych działań, lecz jest wyraźnym sygnałem ze strony wychowawcy do skorelowania działań wychowawczych rodziny i szkoły, czasem także i Kościoła, jeśli autorem wysyłanych wiadomości jest katecheta i przekazuje on zaproszenia do aktywnego udziału w życiu parafii.

Inicjatywy dotyczące zaangażowania rodziców (grupa na portalu społecznościowym czy newsletter) są o tyle cenne, że umożliwiają poruszenie problemu tam, gdzie on powstaje. Tematyka może dotyczyć również samej cyberprzestrzeni - czasem potrzeba uświadomić rodzicom, jak niebezpieczne jest pozostawienie dziecka przed komputerem bez należytego nadzoru, czy konieczność zastosowania blokad dla niepożądanych stron www.

Warto podkreślać także wychowawcze walory cyberprzestrzeni odnoszące się wprost do działalności katechetycznej, zatem możliwości wspierania formacji religijnej z użyciem nowoczesnych środków technicznych. W ślad za papieżem Janem Pawłem II, Benedyktem XVI oraz obecnym następcą św. Piotra - papieżem Franciszkiem, należy podkreślać wielką pomoc cyberprzestrzeni $\mathrm{w}$ docieraniu $\mathrm{z}$ orędziem chrześcijańskim. Wyrazem tego będzie promowanie stron i portali bezpiecznych dla uczniów, o charakterze religijnym; wskazanie na Internet jako źródło rzetelnych treści 
religijnych zamieszczanych przez autorytety z zakresu wiary i moralności, a także przestrzeń kontaktu ze słowem Bożym i nauczaniem Kościoła. Wirtualny świat sprzyja także przybliżaniu się świata realnego - oddalonego o setki i tysiące kilometrów. Za sprawą nowoczesnych technologii informacyjno-komunikacyjnych uczniowie nie tylko mogą słuchać czy czytać o zabytkach sakralnych lub innych miejscach świętych, ale także niejako przenieść się w nie za sprawą wirtualnych wycieczek. Nie ulega wątpliwości, że tego typu kontakt z omawianymi miejscami czy zabytkami pozwoli na głębsze odczucia, a co za tym idzie - bardzie dogłębne przeżywanie rzeczywistości, o której jest mowa.

Wychowanie w cyberprzestrzeni niewątpliwie jest wyzwaniem dla wychowawców, bowiem pojawiają się nowe wyzwania i okoliczności działania, w których muszą się oni odnaleźć. Dynamiczne zmiany zachodzące w kolejnych pokoleniach sprawiają, że korzystanie z dawnych sposobów i metod działalności wychowawczej nie zawsze przynosi zamierzone owoce. Jednocześnie to, co dostarcza problemów i trudności w wychowaniu dzieci i młodzieży, może być odczytywane jako dobre narzędzie realizacji zadań wychowawczych. Wydaje się, że w ten sposób wychowawcy winny patrzeć na cyberprzestrzeń - jako na obszar, który najpełniej odsłoni prawdę o wychowankach. Jednocześnie Internet staje się narzędziem, z którego można korzystać. Należy zatem otwierać się na tę nową - wirtualną rzeczywistość i bez większych obaw szukać w niej pomocy. Jak bowiem zauważył papież Benedykt XVI, „otwierają się obecnie nowe, dotychczas niewyobrażalne cele. Powodują one zdumienie z powodu możliwości, jakie dają owe nowe media, a jednocześnie pilnie wymagają poważnej refleksji na temat znaczenia komunikacji w erze cyfrowej (...) Jak każdy inny owoc ludzkiego geniuszu nowe technologie komunikacji należy umieścić w służbie integralnego dobra osoby i całej ludzkości. Jeśli są one mądrze wykorzystane, mogą pomóc w zaspokojeniu pragnienia sensu, prawdy i jedności, które pozostaje najgłębszym dążeniem człowieka".

Aneta Rayzacher-Majewska, Warszawa

4 Benedykt XVI, Prawda, przepowiadanie i autentyczność życia w erze cyfrowej, Orędzie papieża Benedykta XVI na 45. Światowy Dzień Środków Społecznego Przekazu, http://www. paulus. org. pl/display,222. html (dostęp: 6 XI 2015). 